\title{
The Existing Risks and Countermeasures of Supervision and Management of P2P Online Lending
}

\author{
Xinyang Li \\ School of Economics and Business, Beijing Jiaotong University, Beijing, China
}

18131912299@163.com

Key words: P2P online lending; risks; supervision

Abstract.P2P online lending is an innovative form of financial organization, which achieves some of the functionality of the existing financial system, and it is a useful complement to the traditional financial system. The problems of P2P online lending in our country are mainly rooted from legal deficiency of private lending, long-term implementation of institutional regulatory model and the policy of financial constraints, as well as relatively weak regulatory behavior and industry organizations. This paper focuses on the various risks that P2P online lending faces. And start from government regulation and industry self-regulation. Attempt to build up a P2P online lending risk prevention institutional framework in the context of financial reform, to promote the transparent development of online lending.

\section{Introduction}

1. Concept of P2P online lending. P2P online lending, that is peer to peer lending platfo rm, which gathers scattered private lending to the Internet through the Internet; data auditin g, capital flows, contracts, and all other formalities are completed via the Internet, so the d emand side of funds and borrowers achieve docking on the Internet. In 2007, P2P online le nding formally entered into China and these companies are mostly located in the southeast coastal areas, which fully learn from foreign experience, while combining with the actual re gional situation, forming a local color of P2P platform.

\section{Developing trend of P2P in our country}

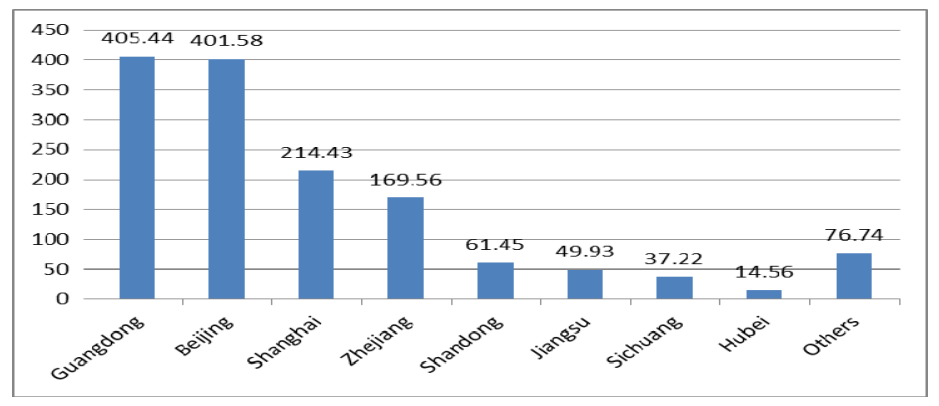

Figure 1 Regional distribution (hundred million) of P2P online lending industry

Based on the relative data, showing that in 2016, in regard to transaction size of P2P lending in the domestic industry, the top three were in Guangdong Province (40.544 billion Yuan), Beijing (40.158 billion Yuan), and Shanghai (21.443 billion Yuan). The gap of transaction size between the top two and the third is very obvious.

Generally speaking, the current domestic P2P lending industry showed regional trends, the developments of P2P lending industry in coastal areas, the more developed regions is more rapid, and transaction size, registered capital, the number of platforms are much higher than the economically underdeveloped areas; the phenomenon of industry gradient is very obvious, the top few occupies a larger share of the domestic industry as a whole. In economically developed regions, regardless of the macro environment, or industry characteristics are far superior to economically 
underdeveloped areas, therefore, P2P lending industry develops very quickly in these areas.



Figure 2 Proportion of newly increased platform issues

As shown in Figure 2, in 2013, the number of collapsed P2P platform is 76, which occupies $14.53 \%$ of the total number of operating platforms; in 2014, the number of collapsed P2P platform is 275 , which occupies $17.46 \%$ of the total number of operating platforms; only in December 2014, the collapsed P2P platform reached 92, exceeding the number of 76 in the full-year of 2013; in 2015, the collapsed platforms is 895 , accounting for $23.20 \%$ of all operating platforms; by the end of February 2016, the number of P2P platforms has reached 3944, of which the total number of problematic platforms reaches 1425, accounting for 36.13\%. P2P platform presents a fast growth rate, high collapse rate, and proportion of the collapsed $\mathrm{P} 2 \mathrm{P}$ platforms occupies the operating platform is constantly rising.

3. Characteristics of P2P online lending platform in our country. At present, P2P onlin e lending enters into the expansion period, analyzing the background of P2Ponline lending platform, it is not difficult to find that P2P online lending platform background is increasin gly abundant nowadays in our country, on the basis of purely private lines, banking system, state-owned system, listed companies, venture capital system are added to the list. Since 2 014, banks, state-owned assets, listed companies, venture capitalists are constantly involved i $\mathrm{n}$ online lending platform to accelerate online lending platform layout. According to incomp lete statistics, the number of online lending platforms which has won the favor of " venture capital " is up to72; listed companies, state-owned shares of state-owned platform is 129; $t$ he number of platforms with banking background is 16 .

List 1 P2P Online lending platform background categories by the end of Feb, 2016

\begin{tabular}{ccccc}
\hline Type & Trading volume & Operation platform amount & Average loan term & Cumulative amount of closure and platform issues \\
\hline Line of banking & 9.055 billion & 16 & 13.43 months & 0 \\
Line of state-owned assets & 10.732 billion & 69 & 4.69 months \\
Line of listed company & 15.777 billion & 60 & 7.56 months \\
Line of venture capital & 23.397 billion & 72 & 10.91 months & 0 \\
Line of private sector & 70.763 billion & 2323 & 7.13 months \\
\hline
\end{tabular}

Different types of P2P online lending platform operating characteristics:

Firstly, judging from average loan maturities, the situation is reversed, the average loan period of banking system was 13.43 months, while the private system was only 7.13 months. Analyzing the reasons, it is mainly because that the demand for borrowed funds from banking system is still some financing projects of the companies, which has enough collateral, and the higher credit rating, so the cost of capital is lower; but the private-based loans has a lower barrier, and the borrowers are usually small and micro businesses or individuals, and the average loan term is short, and it is mainly used as turnover of capital, but due to the borrower's credit rating level is difficult to evaluate, so the platforms face large risks, only to attract investors through high interest rates. But it 
is worth noting that more than 91\% of P2P online lending platforms are private lines of the total number of platform, they are still the main force of the P2P online lending platform, so the overall balance of the loan is huge. Finally, judging from the number of problematic platforms, only private-based platforms have more serious problems in our country; by the end of February 2016, there are at least 1425 private-line platforms face serious problems. The reason is mainly due to the private line access threshold is low, and there are no on ways can increase its credit at the beginning of its development as venture-based platforms do, so it is usually with high interest rates (the average interest rate is 20.55\%) to attract investors, coupled with risk control management is not in place, resulting in highly prone to operational problems.

\section{The existing risks of P2P online lending in our country}

P2P online lending mainly relates to four main subjects: the borrower, lender and third-party individuals or institutions, so the following articles start from the four main subjects.

1. Platform institutional risks

1) Legal risks. At present, $P 2 P$ online lending platforms are only needed to register in industrial and commercial bureau and telecommunications bureau, and the nature of it is "Internet information services industry" rather than financial institutions. Therefore, P2P online lending faces "three abstention" issues, which are no barriers for market access, no industry standards, and no regulatory agency.

2) Network information security risks. $P 2 P$ online lending is based on internet, making it difficult to avoid network information security risks, such as hacker attacks on internet sites, etc., which will not only cause problems to operation platform itself, more importantly, it may cause disclosure of users' information, which will indirectly induce investors to panic .

3) Risk of platform management itself. Risk of platform management refers to the problems as venture capital control, management, product design , etc. that the platform may face, resulting in post-loan funds cannot be recovered on time, funds strand breaks, and investor withdrawals difficulties and other risks.

\section{Risks caused by borrowers}

Risks caused by borrowers mainly include credit risk, also called default risk, which is the risk of economic loss when the transaction opponent failed to fulfill a contractual obligation of the contract.

1) Risks caused by uncovered. P2P online lending platform service objects are usually unable to provide collateral, which are excluded from traditional financial services whose solvency is generally weak. P2P online lending platform provides loans to unsecured borrowers, so the credit risks are extremely high.

2) Risks caused by loan contract without signing in generated. Commercial banks issue personal loans need to execute loan interview and visa interview system, as well as sign a written loan contract. While, the borrowers and lenders of P2P online lending platform reach an agreement through online communication, and the final loan agreement is an electronic promissory note, simply rely on the network to achieve symmetry of information and credit identified patterns are difficult and of great risks.

3) Risks caused by unlimited use of proceeds. Since 2008, the CBRC has promulgated Personal Loan Scheme and a number of regulations to have a strict management over the uses of loans borrowed by the borrower.

4) Risks caused by non-payment of interest below 4 times. In 2002, the central bank promulgated Notice on People's Bank of China Ban Underground Banks and Combat Usury Acts; it 
stipulated that loans with more than four times above the benchmark interest rate should be defined as usury. But look at the current borrowing interest rate of $\mathrm{P} 2 \mathrm{P}$ online lending platforms, a considerable part of the interest rate is three times higher than the bank lending rate, once the borrower defaults to pay interest rates four times exceeding the national portions, the lenders and platforms will obtain no policies and laws support.

\section{Risks of borrowers}

1) Risks caused by using the platform for money laundering. Lender is a party of funding source in P2P online lending mode. Under normal circumstances, lenders use their idle funds for financial investment. However, due to the low threshold to become lenders, lending relationship is formed entirely by autonomy of will, the times that the lenders provide loans in the same P2P platforms, and in different platforms are also unrestricted. P2P online lending platform cannot audit the legitimacy of its source of funds, and most platforms do not set up a sound anti-money laundering internal control system in accordance with the requirements stipulated in Laws of Anti-Money Laundering, Anti-Money Laundering Regulations of Financial Institutions, so the trading platform is likely to become a usury place that the lenders engage in money laundering and other crimes.

2) Risks caused by adverse selection. For borrowers, P2P online lending exist serious information asymmetry. Borrowers' information disclosure is very limited, and the information is provided by the borrowers themselves, while the platform also relies mainly on the information to assess the borrower's credit rating, in which case people are prone to have "adverse selection" and other acts. In P2P platform, adverse selection lead to false information, and the borrowers with greater risks gradually gain the upper hand, while those high-quality borrowers who really need the funds is difficult to get loan, so the high-quality borrowers gradually withdraw from the market, as a result, P2P platforms are filled with "inferior borrower", and the lender's interests are extremely vulnerable.

4. Risks caused by a third party personnel or institution. In the P2P platform model af ter variant, P2P, platform may work with a third-party personal, security companies or small loan companies, by whom provide loan guarantee and audit. P2P platforms are highly asso ciated with these third parties, causing the associated risks. Generally speaking, the platform control a third party's accounts, credit review and rating agencies, and both parties' facilita ting agency, and the internal platform formed a circle, so the transaction is extremely cover $\mathrm{t}$ and highly interconnected. If audit, selection, registration and settlement of funds, debt pac kaging and transference of the lenders and the borrowers are completed by strong associatio $\mathrm{n}$ institutions, it can easily cause moral hazards such as false creditor's rights, false increase $\mathrm{d}$ credit and false bidder.

\section{Countermeasures of supervision and management of P2P online lending in our country}

The presence of the many risks and problems of P2P online lending are derived largely from non-strict venture control and blank legal policy. So I think we can start to build P2P online lending risk prevention legal framework from the following aspects:

\section{Supervision from government}

Effective regulatory is the barrier for financial system stability, which is an important aspect to ensure a competitive financial system. Therefore, only placed the platform under specific law regulation, and specialized regulators can it creates a good living environment for P2P online lending platform.

1) Clear supervising subjects. China Banking Regulatory Commission and its agencies have the 
right to supervise the establishment, change, termination and the business scope of the banking institutions, for non-bank financial institutions, CBRC implements regulation on business. The nature of many P2P online lending platforms can be regarded as quasi-financial institutions, and its operations will affect the credit market, these two points are displayed that the rights and liabilities of regulation on $\mathrm{P} 2 \mathrm{P}$ online lending should belong to the CBRC and its agencies.

2) Enact supervision standards. Regulation content should include the following aspects:

\section{(1) Clear market admittance criterions}

Market admittance criterions can be divided into access to capital, access to products and services, access and practitioners and so on, maintain financial market order and protect the interests of investors from different angles respectively. In addition, the platform should also have anti-money laundering measures, a sound organizational structure and internal control and risk management systems which meet the requirements. In addition, besides completing the necessary business registration, P2P platform also need to proceed register for record in CBRC and its local agencies.

\section{(2)Supervision over transaction process}

\section{a) Reinforce pre-audit of lending}

P2P online lending platform should have certain audits on the borrowers' lending project to ensure that the interests of investors. For lenders, the audit should focus on their sources of funds to find out whether the unscrupulous staff use online lending platform to dispose their gray income; and for the borrowers, substantive examination should be carried out over the use of funds, the funds cannot be used for criminal activities: for the review of the loan contract, one should pay attention to whether the agreed interest rate is four times below the legal requirements of the bank loan.

\section{b) Set up funds trusteeship}

To prevent unauthorized misappropriation of borrowed funds, P2P online lending platform should establish a special fund escrow account in a bank or a third-party payment agency, separating from their own platform account funds. Lenders directly put their funds into the escrow account through online banking or a third-party payment platform, and the trustee agency will supervise the flow of funds in the account to restrict cash withdrawal and remit account of borrowers, lenders and the platform to guarantee financial security.

\section{c) Set up loan risk reserves system}

The risk reserves of the platform are mainly from a certain percentage of the amount of each loan provision that the platform withdraws, and for independent own funds and borrowed funds of the platform, once the loans overdue, the platform will use the risk reserves to repay the borrower all or parts of the losses, and the platform will get the rights of recourse of the creditor's rights so that it can continue to recourse to the borrower.

\section{d) Reinforce information disclosure}

The operation of $\mathrm{P} 2 \mathrm{P}$ online lending platform has a certain complexity and concealment. So it is required mandatory disclosure of relevant information to the public, and the disclosure information should include changes in the registered capital and the capital custody reports, product descriptions, risks control, and changes in the composition of senior management. In addition, the platform also needs to fulfill their obligations to the regulatory body, including the periodic reports and interim reports.

\section{e) Enhance confidentiality awareness}

P2P online lending platform should be required to keep basic information about the user's identity, lending and other business information, keep business secrets for the users. Platform can carry out technological innovation, and improve the site equipment to enhance the ability of preventing hacker attacks, and preventing information leakage. 
3) Design market exit mechanism. As special non-financial institutions legal persons, there are many differences in the exit mechanism between P2P online lending platform and companies in general, when exiting, pay special attention to the protection and maintenance of personal information of the customers on unexpired loan contract.

\section{Industry self-regulation supervision}

In fact, industry self-regulation of P2P online lending platform in our country has come to the front of the legal regulation. In August 2013, China Microfinance Alliance officially released Industry Self-Regulation Conventions on Peer-to-Peer (P2P) Micro-Credit Information Consulting Services; $\mathrm{P} 2 \mathrm{P}$ online lending industry associations from place to place have also been established. The first step of industry self-regulation is to establish an information sharing platform within the industry, particularly credit information sharing mechanism, and publish blacklists of users and so on. The second step is to establish a risk pre-warning mechanism, urging members to submit business reports and risk indicators data on an annual basis to facilitate monitoring. The next step is to form a positive interaction and cooperation with government regulation. Finally, there should be a corresponding punishment mechanism to give some punishment to those who break self-regulatory rules. Only in this way can the industry self-regulation be implemented, and give full play to the role of self-regulatory organizations on $\mathrm{P} 2 \mathrm{P}$ online lending platform.

\section{Conclusions}

$\mathrm{P} 2 \mathrm{P}$ online lending is a new thing in our country and around the world, and it is developing at a pace that the traditional banking business unparalleled, in order to make the industry have a healthy and orderly development, the government must take correct measures to supervise it.

\section{References}

[1] Chen Xiao Study on Cost of Private Lending - Empirical Analysis Based on P2P Online Lending [J] Financial Economics, 2014,01: 37-48.

[2] Wen Xiaoni, Wu Xiaojuan Success Factors on P2P Online Lending - Take PPDAI As an Example [J] Finance Forum, 2014,03: 3-8.

[3] Fan Yunhui Operation and Legal Supervision on P2P Online Lending [J] Economic Issues, 2014,12: 53-58.

[4] Yang Zhenlong Legal Analysis and Regulatory Study on P2P Online Lending Platform Operating Behavior [J] Financial Regulatory Research, 2014,11: 25-41.

[5] Liu Hui, Shen Qingjie International Experience on P2P Online Lending and Supervision Reference to China [J] Hebei University of Economics and Technology, 2015,02: 56-61.

[6] Guo Yang Study on P2P Microfinance Development Current Situation [J] Shanghai Finance, 2012,12: 19-22 + 120 .

[7] Wang Pengyue, Li Jun History, Current Situation and Prospect of US P2P Lending Platform Development: [J] Financial Regulatory Research, 2013,07: 26-39. 